\title{
TRAPPING ALIENS: UNDERSTANDING THE COMPLEXITIES OF CONTROLLING INTRODUCED FRESHWATER CRAYFISH IN THE UNITED KINGDOM
}

\author{
Emily ADAMS * \\ * Elsner Research and Consulting, Witikonstrasse 4, Pfaffhausen, Switzerland, CH-8118, \\ emilyadams13@gmail.com
}

DOI: 10.1515/trser-2015-0086

KEYWORDS: Pascifastacus leniusculus, signal crayfish, invasive, management, trapping, stakeholder, crayfish.

\section{ABSTRACT}

Invasive non-native species pose practical and ethical problems for the people tasked with their management. Invasive freshwater crayfish species in the UK threaten rare native crayfish and freshwater habitats, yet their control is beset with social, practical and environmental barriers to success. This paper draws on an interdisciplinary study of stakeholders involved in crayfish management in East Anglia to explore the management of non-native freshwater crayfish in the UK. It concludes that when standard methods of control fail, stakeholders are willing to consider unusual management suggestions such as commercial trapping, whilst recognising that these may bring their own problems.

ZUSAMMENFASSUNG: Fremdländische Arten einfangen: zum Verständnis der Komplexität der Kontrolle zugewanderter Süßwasserkrebse in Großbritannien.

Invasive, zugewanderte Arten stellen für diejenigen, die mit ihrem Management betraut sind, praktische und ethische Probleme dar. So gefährden die invasiven Süßwasserkrebsarten Großbritanniens seltene, heimische Flusskrebsarten und deren Habitate und dennoch ist deren Kontrolle und Erfolg umgeben von Hindernissen aus dem sozialen, praktischen und dem Umweltbereich. Vorliegende Arbeit umfasst eine interdisziplinäre Studie von Interessenvertretern, die in das Management des Flusskrebses in Ost-Anglia eingebunden sind, um die Behandlung der invasiven, fremden Arten zu erforschen. Aus den durchgeführten Untersuchungen folgern sie, dass bei Versagen der Standard-Kntrollmethoden auch unübliche Managementvorschläge in Betracht gezogen werden können, wie zum Beispiel wirtschaftliches Fangen, solange zugegeben wird, dass diese auch ihre eigenen Probleme mit sich bringen können.

REZUMAT: Prinderea în capcană a străinilor: înţelegerea complexităţii controlului introducerii racilor de apă dulce în Regatul Unit.

Speciile invazive pun probleme practice și etice persoanelor responsabile cu gestionarea acestora. Speciile invazive de raci din Marea Britanie amenință racii de apă dulce nativi, foarte rari, şi habitatele lor, şi totuşi controlul lor este blocat de bariere sociale, practice și de mediu. Această lucrare se bazează pe un studiu interdisciplinar al părților interesate implicate în managementul racilor din Anglia de est, pentru a explora gestionarea racilor de apă dulce non-nativi, din Marea Britanie. Se ajunge la concluzia că, atunci când metodele standard de control eșuează, părțile interesate sunt dispuse să ia în considerare sugestii de gestionare neobișnuite, cum ar fi capturarea comercială, recunoscând în același timp că aceasta poate aduce propriile ei probleme. 


\section{INTRODUCTION}

Managing invasive non-native species (INNS), species which have been introduced by human action outside of their range and which pose a threat to biodiversity in their new locale (Defra, 2008), is a key environmental management challenge, as they are regarded as an internationally important issue for conservation (Millennium Ecosystem Assessment, 2005; Hall, 2003). Invasive NNS are a primary driver of ecological degradation through competitive interactions such as predation, resource competition, habitat alteration, disease transmission and hybridisation (Manchester and Bullock, 2000; Clout, 2002). INNS cause economic as well as nature conservation problems, through reduced harvests of commercial species and the costs of combating invasions through quarantine, control and eradication (Manchester and Bullock, 2000; Mack et al., 2000). INNS are therefore a major focus for environmental management with increasing investment in local, national and regional programmes, such as the Great Britain Non-Native Species Secretariat (NNSS) and the EU's Delivering Alien Invasive Species Inventories for Europe programme (DAISIE) (Roy et al., 2014).

Managing invasive species typically requires co-operation between many stakeholder groups, which can be challenging as they can have different priorities and interests, making collaboration difficult (Stokes et al., 2006). Co-operation between stakeholders (scientists, conservation managers, commercial, industrial and public sectors) is therefore necessary for such efforts to be sustainable in the long term (Stokes et al., 2006). This issue is especially pertinent to freshwater environments, which are particularly vulnerable to invasion (Moorhouse and Macdonald, 2015), both due to the interconnected nature of many aquatic habitats (Ramsar, 2003) and because they often have complex management systems as a result of multiple stakeholder and user groups with different rights and responsibilities (Stokes et al., 2006; EA, 2009).

Therefore, understanding attitudes and perceptions to INNS management is very important. However, scientific discourses often ignore factors such as values and interests, despite the fact that these often shape discussions and drive engagement with such topics (Gozlan et al., 2013; Selge et al., 2011). Public attitudes towards management of wildlife in the UK indicate a general support for eradicating INNS posing a threat to human health, native species or causing economic damage, although the level of support is context-dependent and tends to be higher for high-profile species such as red squirrels (Bremner and Park, 2007; Defra, 2009). However, public opposition to INNS control can delay interventions to the point that eradication becomes impossible (Selge et al., 2011).

\section{Managing invasive crayfish in the United Kingdom}

The UK has well-established populations of non-native crayfish species, dating back decades. Freshwater crayfish are a diverse group of decapod crustaceans, many of which are endangered (Crandall and Buhay, 2008). However, a small number of species are widely distributed outside their native range, primarily through the aquaculture, pet and live bait trades (Holdich et al., 2009). Their roles as key organisms in many food webs make their introduction significant (Lindqvist and Huner, 1999). In Europe, invasive non-native crayfish are responsible for major shifts in ecosystem structure and dynamics (e.g. Gutierrez-Yurrita et al., 1999). The UK has one native crayfish species, the white-clawed crayfish (Austropotamobius pallipes), currently protected under Annex II of the EU Habitats Directive (JNCC, 2010) and seven invasive species, the most widespread of which is the signal crayfish (Pacifastacus leniusculus) (Holdich et al., 2009). 
Collapse of commercially important native European crayfish from crayfish plague (Aphanomyces astaci) in the 1970's led to widespread introduction of resistant non-native species as replacements (Lowery and Holdich, 1988). The UK lacked a commercial fishery for crayfish but signal crayfish were introduced for export to European markets (Lowery and Holdich, 1988; Holdich et al., 1999a). Most farms failed and were abandoned. Signal crayfish populations adapted well to the UK, expanding rapidly through well-used and interconnected waterways (Lowery and Holdich, 1988). Declining habitat quality was also identified as an important reason for the wide spread of signal crayfish in the UK, as it is recognised that poorquality habitats are more vulnerable to invasion by INNS (Manchester and Bullock, 2000; Mack et al., 2000).

Signal crayfish today rank as one of the best-known and most regularly mentioned INNS by environmental managers in freshwater environments (Williams et al., 2010; Gozlan et al., 2013), and are thought to cost the UK (in terms of lost revenue from water-users and anglers, costs for removal and for habitat restoration and protection for the native white-clawed crayfish) around £1,502,000 per annum (Williams et al., 2010). In addition, their population continues to expand across the UK (NNSS, 2011). Thus, signal crayfish are a major issue for freshwater environmental managers.

This paper explores the complexities of managing signal and other invasive crayfish species in the UK from a stakeholder perspective. It focuses on three key challenges for stakeholders involved in the management process which range across social and natural themes: selecting the most appropriate control method; implementing and enforcing existing legislation; and building partnerships between different stakeholder groups. The paper concludes with a brief discussion about the potential for using harvesting as a control mechanism, following the growing cultural interest in "wild foods" (Reyes-Garcia et al., 2015).

\section{METHODS}

This paper draws on fifteen in-depth interviews carried out between June and August 2010 with river managers, crayfishers and academics working on freshwater environments in East Anglia. This area was selected because non-native crayfish are a significant issue in the region and several local angling clubs and other organisations have worked on crayfish management.

A local researcher and angler was approached to act as gatekeeper for contacts, and the researcher met them several times in order to discuss the project and its aims (Valentine, 2005). A snowball technique was used to recruit contacts, from which the author selected a sample of interviewees including national and local government bodies $(n=3)$, navigation authorities $(n=1)$, local authorities $(n=2)$, local angling or river clubs $(n=3)$, academic NNS researchers $(n=3)$ and unaffiliated stakeholders including crayfishers and landowners affected by crayfish $(n=3)$, who could provide insights into the issues and opinions surrounding management of non-native crayfish.

A list of key questions was used to guide interviews, provided in advance if requested (Valentine, 2005; Robson, 2007). During the interview, if a new topic was introduced, it was followed up, and the key questions for subsequent interviews adjusted to include it. Most interviewees were interviewed in their offices or homes, with two interviewed by telephone. All interviews were recorded on a digital voice recorder, and stored as mp3 files on a computer. Transcription by the author took place as soon as possible after the interview, to 
allow notes, ideas and clarification to be included on the transcript, and to familiarise the author with the material (Crang, 2005). The format of the transcript was an interview report, rather than a verbatim transcript (Crang, 2005) permitting interviewees to more easily see whether their ideas had been well recorded (Jones, 2008). The analysis and results are presented using quotations from interviews woven into a synthetic narrative about signal crayfish management and stakeholder interactions (Adams et al., 2004; Jones, 2008). Where necessary, quotes have been edited with square brackets to maintain anonymity or coherence.

Note on language: Interviewees used different phrases to describe NNS, e.g. "invasive species" or "alien species", and these have been quoted verbatim. The author has used nonnative species (NNS) or invasive non-native species (INNS) throughout the rest of the text. This latter term refers explicitly to species that, on their arrival in a new area, are regarded as causing significant issues or other species, or which expand rapidly.

\section{RESULTS}

\section{Choosing methods of control}

The first major challenge in controlling signal crayfish is selecting a method to control them with. Signal crayfish are tough, omnivorous and mobile, tolerant to the UK's temperate climate and able to live in a diverse range of habitats (NNSS, 2011). A variety of methods are used to control non-native crayfish, including mechanical removal, poisoning or biocide and physical barriers (Holdich et al., 1999b; Freeman et al., 2010; Stebbing et al., 2014).

Biocide applications have not been widely used in the UK, but early trials in enclosed water bodies like ponds have been successful (Peay et al., 2006). It is possibly the only method that will completely eradicate crayfish as long as $100 \%$ of crayfish are killed (Peay, 2001). Unfortunately, signal crayfish are resistant to many biocides and pesticides (NNSS, 2011). Two stakeholders (both regional environmental management officials) who favoured biocide as a control method generally agreed that biocide applications are only appropriate in certain places, generally as a spot treatment, because the toxins used are not crayfish-specific, and in large water bodies like rivers the collateral damage is high (Holdich et al., 1999b; Peay, 2001). However, other stakeholders, particularly anglers, were not happy about the use of biocides with one angler commenting that using biocides was deliberately "creating an ecological incident" (interview with angler). Stakeholders who were interested in native crayfish conservation (a mix of officials, anglers and researchers) also expressed concern that biocide would have no effect on crayfish plague (carried as a latent infection by signal crayfish but lethal to white-clawed crayfish, NNSS, 2011), so its use in creating white-clawed crayfish refuges might be limited.

Several stakeholders mentioned that work was proceeding on finding a control method based on pheromone trapping, although no one mentioned any successes (Holdich et al., 1999b; Stebbing et al., 2002). This is an area recommended in the NNSS risk assessment for signal crayfish as an area in need of work. In terms of a wider focus on biological controls on signal crayfish, native predators are known to have a critical role to play in controlling populations of NNS (Rabeni, 1992; Hill and Lodge, 1994; Juliano et al., 2010). Hein et al., (2007) found that reducing fishing pressure on predatory fish contributed to crayfish population reductions. Non-native crayfish in Spain and France support populations of predatory species like otters, eels and bitterns, which in turn act as a control on crayfish population sizes (Musseau et al., 2015; Barrientos et al., 2014; Poulin et al., 2006; BlancoGarrido et al., 2008). In the UK, native crayfish predators include otters (Lutra lutra) and carnivorous fish like eels (Anguilla anguilla), both of which were identified by stakeholders as potentially important factors in controlling signal crayfish populations, with one trapper saying 
"to some extent, crayfish have been good news for otters, as they eat them ... if otter populations got big enough, it could be very useful" (interview with crayfish trapper). However, otters also pose a threat to fishing operations, as an environmental management official explained: "They (crayfish) can supplement the diet of otters when they fail to catch fish, so the energy pressure on otters which acted as a (population) control is lost, so otters can keep chasing fish" (interview with regional environmental management official).

The use of barriers to prevent expansion of signal populations up- and downstream has been applied in a few cases (e.g. Reeve, 2004; Kerby et al., 2005), but is complex, especially over long time periods, and can cause other issues such as access for migratory fish and other species. Other habitat alteration ideas include creating chemical barriers to signal crayfish expansion, e.g. by altering water acidity/alkalinity. One such case study on the River Clyde, Scotland (Reeve, 2004), was widely cited by stakeholders interviewed. Most acknowledged that there would probably be side effects on other species, but felt that this negative would be outweighed by the benefits of a reduction in crayfish populations: "If, by changing the $\mathrm{pH}$, we reduce the number of crayfish, and everything else improves, overall this is good" (interview with local environmental authority official).

Studies on the dewatering of burrows (Peay and Dunn, 2014) suggest that whilst it can remove signal crayfish from an area, they are able to cross dry land, and dewatering encourages such movement, potentially increasing their colonisation of new areas.

The easiest method to control crayfish is via baited traps laid on riverbeds. Trapping is widely accepted not to eradicate crayfish populations, as traps can be selective for large males, and removal of large males increases the recruitment of juveniles, leading to a sustained population (NNSS, 2011; Momot, 1998; Hein et al., 2007). Most stakeholders cited this research, with one neatly summarising it by saying that trapping: "Removes the large cannibalistic individuals and promotes dispersal of smaller individuals" (interview with national invasive species advisor).

However, intensive trapping over several years causes a decline in catch rates over time, which, whilst not eradicating signal crayfish, does maintain a low population and allow macrophyte, invertebrate and fish populations to increase, which are all negatively affected by large crayfish populations (Hein et al., 2007). This effect was observed by many of the anglers and trappers interviewed for this study. Members of a local angling club which has trapped signal crayfish intensively for some years have observed improvements to their river environment, with more fish fry, insects and small fish. Individuals involved in long-term trapping commented that "I have trapped this area solidly for five years, and I have noticed a reduction in population and size ... I do think I have made a huge difference to the area" (interview with trapper) and "If I do a second day (of trapping), I tend to notice a falling off. I have fished for three days in a row, and had very few on the third day" (interview with trapper).

Trapping is a long-term control method - unless trapping pressure is maintained, populations will recover and continue to expand (Hein et al., 2007). An angler involved with his local angling club's trapping project indicated that they had thought hard about starting, because "when we started, we knew it was not going to be a short term fix, but a long term commitment" (interview with angler). 
The conclusion from this section, and from reports such as the NNSS risk assessment for signal crayfish (NNSS, 2011), is that there is no one method that will successfully deal with signal crayfish. Instead, each affected area has to work within environmental and practical limits - if possible, to use extreme methods such as biocide to remove signal crayfish, but where that is not practical to focus on developing new methods such as pathogen-based controls (Freeman et al., 2010) or use time and personnel-intensive methods like trapping.

\section{Bureaucracy, licensing and enforcement}

Carrying out control measures against NNS is often fraught with uncertainty, but failure to act quickly following the initial arrival of INNS can result in serious problems later on (Coblentz, 1990). In the case of signal crayfish, the legislative environment in which it was first introduced was also an important factor, as one NNS expert commented: "The lesson has been learnt from signal crayfish - there are not always happy endings with invasive species they need to be caught early and hard to be effective" (interview with national invasive species advisor).

INNS legislation is often piecemeal and designed in response to a particular problem, and thus of variable effectiveness (Fasham and Trumper, 2001). Following criticisms around existing UK legislation on INNS, a Defra policy review was carried out in 2003 (Defra, 2003), from which the GB NNS Strategy was developed (Defra, 2008). The Strategy adopts a precautionary approach, aiming to better balance reactive management with preventative work such as species alerts and horizon scanning (Defra, 2008), and has also focused on awareness raising campaigns to reduce inadvertent introductions of potentially invasive species by focussing on good management practices, e.g. "Be Plant Wise" for invasive pond weeds (NNSS, 2009).

Rapid response infrastructure in the UK is being developed, especially for invasive aquatic species like the top-mouth gudgeon (NNSS, 2010), and would be potentially valuable against new invasive crayfish species, e.g. Procambarus fallax forma virginalis (Scholz et al., 2003; CABI, 2015). However, this is too late for signal crayfish: "If we had had a rapid response capacity with signal crayfish (in the 1970s), we could have eradicated them when they were still only in ponds" (interview with regional invasive species co-ordinator).

Signal crayfish legislation is still somewhat confusing, as one stakeholder explained: "Requests for (signal) crayfish trapping go to the EA (Environment Agency) ... requests to do research trapping (e.g. capture-mark-recapture) (on white-clawed crayfish) have to go to Natural England, who implements the Wildlife and Countryside Act 1981 ... (and) enforcement of the Act (Wildlife and Countryside Act 1981 which makes it illegal to introduce non-native crayfish to the UK) is through the EA. Additionally, CEFAS and Defra are involved" (interview with regional environmental manager).

The Environment Agency requires individual trapping for crayfish to have a license (EA, 2010a), designed to prevent illegal trapping, or trapping in sensitive areas. Stakeholders holding licences were critical of the process, saying that the relevant sections on the Environment Agency website were hard to find, and that the licence form was hard to fill in: "On the form there is a bit for landowner permission and location ... I contacted the EA Properties department to ask how I could find out about landowners. They had no idea and suggested I went knocking on doors" (interview with angler). Others commented that enforcement of license renewal was poor: "I am meant to have a Defra license, and did have one for two years, but now I can't be bothered, as no one has said anything” (interview with trapper). 
Further, trappers who had complied with the license requirement to give catch returns to the Environment Agency (EA, 2010b) were frustrated by a lack of feedback, disincentivising them to renew their license: "I sent the EA my catch data and never got any acknowledgement, so what is the point in doing it? ... I would have been very interested to see what it showed" (interview with trapper).

Currently, trapping is only licensed in certain "go" areas where there are no populations of the protected white-clawed crayfish (Austropotamobius pallipes) (HMSO, 1996). A major concern for many stakeholders was the potential for confusion between whiteclawed and signal crayfish. Stakeholders mentioned that many people didn't know about white-clawed crayfish, and indicated that because the licensing system does not require training in crayfish identification, and does not clearly indicate the "go" and "no-go" areas for fishing, mistakes were more likely to happen (Peay, 2010). Improved identification skills were seen as key to solving this: "I have no problem with public fishing, as long as the people have had a degree of education. It should be conditional on getting a license, but it isn't" (interview with angler).

Officials dealing with signal crayfish management also raised concerns over the association of trapping with bycatch of protected crayfish predators like otters: "We have a big problem with illegal fishing and otter bycatch. Whenever EA staff go out and remove traps, they will find dead otters" (interview with regional invasive species co-ordinator).

These issues are recognised by the fishing and trapping communities, with one trapper suggesting that the EA could improve its trap licensing process to reduce the risk of by-catch and illegal trapping by having: "a website that says where you can fish crayfish, what sort of trap you should use, they could even sell the nets" (interview with trapper).

All stakeholders concluded that stronger trapping regulation was necessary, with one official working on national invasive species strategy commenting that "the licensing system, whilst it is clunky, does allow some sort of regulation" (interview with national NNS co-ordinator).

The issues around dealing with legislation and enforcement of legislation are made more difficult by the diverse range of stakeholders involved in crayfish management. Engagement of local stakeholders (e.g. land-owners, anglers, etc.) can be really beneficial for government bodies strained financially: for example, the Local Action Groups organised and co-ordinated by the NNSS have been a successful model for public engagement in INNS control (NNSS, 2015). However, issues arise when enforcement is weak/ineffective (as observed here) or when opinions diverge on how things should be done. The following section delves into these issues further.

\section{Expertise, partnership and interests}

Improved co-operation and co-ordination helps to achieve long-term effective protection against invasions (Taugbøl and Skurdal, 1999; Stokes et al., 2006). Stakeholders mentioned increased local and national co-operation over NNS work as positive. Nationally, the establishment of the GB Non-Native Species Secretariat (NNSS) and Strategy has: "Cut through debates about whose responsibility it was to deal with invasive species, particularly between the EA and NE, and laid out how the work should be done" (interview with national advisor on invasive species).

The UK has an advantage over much of Europe, as its freshwater habitats are geographically isolated from mainland Europe, and has a body like the NNSS, which can 
co-ordinate horizon scanning and surveillance activities for potential INNS (Defra, 2008). This places the UK in a good position to react to new INNS arriving, although does not prevent new species arriving (10-12 new INNS become established every year in the UK, NNSS, 2015).

However, despite the advantages of a co-ordinated approach to INNS management, there remain uneasy relationships between some stakeholders. Some trappers felt that attitudes towards individuals like themselves within the policy world were not always positive: "The EA's attitude to fishermen (and their ability to identify things) is patronising" (Interview with angler). They felt that their expertise and experience were not fully appreciated: "There is a certain amount of elitism which has been a problem - so much information on crayfish has come from academics that it is only more recently that they are willing to listen to other people" (interview with trapper).

One trapper felt that many people working for official organisations had lots of qualifications but relatively little experience compared to people without an academic record but who have spent a long time living or working in an area. This is not a phenomenon restricted to the case study area: generally, those in policy favour information coming from scientific and academic sources over that from other sources (Beck, 1992; Leach and Scoones, 2005). In contexts where the success of a project may depend on the good-will and engagement of non-scientists such as trappers and anglers, this sort of attitude can lead to problems (e.g. Wynne, 1992).

However, it is not just about attitudes to engagement: sometimes agreeing on how to manage the environment can be difficult between different stakeholders (Selge et al., 2011). A good example of this is the potential conflicts of interest between anglers and environmental managers over freshwater INNS management options: the UK has seen an increase in "big game" angling, which has led to increasing demands for stocking of fish types (Hickley and Chare, 2004). Fish stocking both presents one of the key routes for signal crayfish to spread to new areas (the larvae and eggs can be transported with fish, NNSS, 2011), and the investment in this industry also becomes an issue when populations of predatory species like otters increases. The support offered to otter populations by large signal crayfish populations has not been seen positively by some anglers in the case study area: "(it is) very problematic - there was a case of two carp killed by otters ... which weighed 35 and $39 \mathrm{lb}$, and cost £5000 each the fisherman lost $£ 10,000$ of investment in total" (interview with regional environmental management official).

Officials said that anglers have demanded that otter populations be controlled, despite their positive effects on freshwater habitats and fish populations through their control of crayfish (Barrientos et al., 2015): "They (anglers) have run big campaigns against otters, especially over the last two-three years" (interview with regional environmental management official).

Thus, some of the solutions to controlling crayfish that are low-impact on the wider environment (i.e. supporting native predators, rather than using harmful methods like biocide or habitat alteration) can be as unpopular as the presence of the INNS themselves, providing serious challenges to those trying to manage the environment for many different users (Hickley and Chare, 2004).

\section{Harvesting invasive crayfish - solution or not?}

Having studied some of the attitudes and approaches of stakeholders charged with managing crayfish, I now return to the question of why signal crayfish were ever introduced, and whether it offers a possible solution going forwards. As discussed in the Introduction, signal crayfish were introduced to the UK as an aquaculture species for export to Europe for 
consumption (Holdich et al., 1999a). In the UK, the last decade or so has experienced a surge in interest in so-called "foraging" or wild harvest of species for consumption, encouraged by TV shows and haute cuisine (Reyes-Garcia et al., 2015; NNSS, 2011). Signal crayfish, as a numerous and widely-present crustacean with a history of consumption in other countries (Taugbøl, 2004), are an obvious target for foragers (e.g. Clay, 2011). The fact that removal of signal crayfish could be regarded as an environmental benefit enhances their attraction (along with consumption of other INNS like grey squirrels, e.g. Davies, 2008). Such an approach has been considered by Defra to control Chinese mitten crabs (Eriocheir sinensis) in the river Thames (NHM, 2008).

In this study, three of the six trappers interviewed trap because they enjoy eating crayfish: "I am fishing for food, not to conserve the white-clawed crayfish" (interview with angler). Stakeholders suggested that a market for wild-harvested crayfish might provide a financial incentive to trap, whilst simultaneously securing labour for projects trying to control crayfish populations.

Whilst in concept attractive, the reality of setting up a commercial enterprise is more difficult, for three reasons: firstly, the market for wild-caught freshwater crustaceans in the UK remains relatively undeveloped, making it hard to find local consumers. As one angler commented, "the biggest problem with them is not catching them but getting rid of them" (interview with angler).

Secondly, there is a contradiction between trapping for conservation, where the main focus is on reducing populations significantly, and trapping for commercial sale, where the interest is on large individuals that are saleable. As one trapper put it, "anything less than eight cm is not really commercial and not worth it" (interview with trapper).

A trapping project for conservation reasons which encourages people to participate by selling their catch is likely to fail over time as catch volume and crayfish size decline and the market value declines in parallel. As one angler pointed out, "a (commercial) trapper at that point would move on" (interview with angler). This is not an option for conservationists who need to maintain low population numbers in order that freshwater habitats can recover. Thus, co-operation and potential subsidies to compensate for declining body sizes and profit would be required for such a project to work long-term.

Finally, and most problematic, is the issue of signal crayfish spread, and the legal aspects of this. As a species listed under the Wildlife and Countryside Act 1981, signal crayfish are not permitted to be released into the wild, yet encouraging commercial harvesting brings the risk of deliberate introduction of signal crayfish to new areas (Gutierrez-Yurrita et al., 1999; Peay, 2010). The NNSS risk assessment for signal crayfish outlines a few case studies where signal crayfish have been introduced deliberately, or where people inadvertently trapped for the protected white-clawed crayfish (NNSS, 2011). Anything that encourages the expansion of signal crayfish or which affects white-clawed crayfish should be very carefully implemented, if at all (NNSS, 2011). Thus, it seems likely that although individuals may choose to consume locally-caught crayfish, the creation of a market that will act to fund the control of signal crayfish is likely to fail. 


\section{CONCLUSIONS}

This paper has outlined a series of institutional and practical challenges and opportunities for signal crayfish management in the UK. There is no single method that will successfully control signal crayfish, reflecting both their habitat (interlinked freshwater environments with many sensitive species present) and their robust life-history. Therefore, as one angler commented: "We have no choice but to accept that the signal crayfish is here to stay" (interview with angler).

However, most stakeholders did not feel that ignoring signal crayfish is an option loss of protected species like white-clawed crayfish, and continued degradation of freshwater habitats as a consequence of growing signal crayfish populations is likely to be problematic for the UK under the EU Habitats and Water Framework Directives (JNCC, 2010; EU, 2000).

The improved policy and legislative environment around INNS management has no doubt benefited national and regional efforts to control them, in part by drawing together government stakeholders, and supporting public awareness of INNS issues. However, this paper has also identified ongoing issues around stakeholder interactions, not least perceptions of groups such as anglers and trappers, who act often from environmentally-oriented reasons but who feel separated from policy and that their knowledge about river environments is not well-regarded (Van Eijck and Roth, 2007). Further, other parts of their communities can directly inhibit the efforts of environmental managers to control INNS, providing new sources of conflict. This small-scale case study is not alone in this, but provides a good example of the challenges facing environmental managers and those wishing to support the environment when trying to work together, not least that the science behind control is difficult and uncertain.

Commercial exploitation of signal crayfish through trapping is an unusual suggestion, and although trapping is widely held not to eradicate signal crayfish, intensive, organised trapping can benefit freshwater ecosystems, reducing signal crayfish numbers and allowing macrophyte, fish and invertebrate populations to recover (Hein et al., 2007; West, 2009). Whilst a system where trapped crayfish are sold to raise funds for control efforts, there are also a number of serious risks associated with such an idea. These are not helped by a confusing legislative environment. Should a commercial approach be used in controlling signal crayfish, it would need to be strictly regulated, and could be designed as a way of encouraging environmental citizenship, an approach successfully used in Europe to protect native crayfish from introductions of invasive species (Taugbøl and Skurdal, 1999).

The issues that emerged from this paper are relevant to wider biodiversity management. INNS are a part of wider issues facing conservation of freshwater ecosystems. Further work could seek to put perspectives on INNS management into a wider freshwater management context.

\section{ACKNOWLEDGEMENTS}

I'd like to thank everyone who kindly gave up their time and allowed me to interview them. I'd also like to thank Peter Jones at UCL Geography Department for supervising my MSc thesis which was the basis for this paper, and Carl Sayer, Sophie des Clers and Sam Randalls at UCL for useful discussions about different aspects of the project, especially during its development stages. This paper benefitted from discussions with Bill Adams, Anne Toomey, Beth Brockett, Anni Fiebig and the Lancaster Environment Centre writing group. 


\section{REFERENCES}

1. Adams W., Perrow M. and Carpenter A., 2004 - Conservatives and champions: river managers and the river restoration discourse in the United Kingdom, Environment and Planning A, 36, 1929-1942.

2. Barrientos R., Merino-Aguirre R., Fletcher D. and Almeida D., 2014 - Eurasian otters modify their trophic niche after the introduction of non-native prey in Mediterranean fresh waters, Biological Invasions, 16, 1573-1579.

3. Beck U., 1992 - Risk Society, Towards a new modernity, Sage Publications, New York, 260.

4. Blanco-Garrido F., Prenda J. and Narvaez M., 2008 - Eurasian otter (Lutra lutra) diet and prey selection in Mediterranean streams invaded by centrarchid fishes, Biological Invasions, 10, 641648.

5. Bremner A. and Park K., 2007 - Public attitudes to the management of invasive-non-native species in Scotland, Biological Conservation, 139, 306-314.

6. CABI, 2015 - Procambarus fallax f. virginalis (Marmorkrebs) in Invasive Species Compendium, Wallingford, UK: CAB International. www.cabi.org/isc.

7. Clay X., 2011 - Catch and eat crayfish to help the environment, The Telegraph Newspaper, September 2nd 2011, http://www.telegraph.co.uk/foodanddrink/8734885/Catch-and-eatcrayfish-to-help-the-environment.html (accessed 16/08/2016).

8. Clout M., 2002 - Biodiversity loss caused by invasive alien invertebrates, Zeitschrift für Jagdwissenschaft, 48, 51-58.

9. Coblentz B., 1990 - Exotic organisms: a dilemma for conservation biology, Conservation Biology, 4, 261-265.

10. Crandall K. and Buhay J., 2008 - Global diversity of crayfish (Astacidae, Cambaridae and Parastacidae - Decapoda) in freshwater, Hydrobiologia, 595, 295-301.

11. Crang M., 1997 - Analysing qualitative materials, in Methods in Human Geography Research, Flowerdew R. and Martin D. (eds), Addison Wesley Longman Ltd., Essex, UK, 218-232.

12. Davies C., 2008 - The ultimate ethical meal: a grey squirrel, The Observer Newspaper, Sunday 11th May 2008, http://www.theguardian.com/lifeandstyle/2008/may/11/recipes.foodanddrink (accessed 16/08/2016).

13. Department for the Environment, Food and Rural Affairs, 2003 - Review of non-native species policy: report of the working group, Defra, London, 30.

14. Department for the Environment, Food and Rural Affairs, 2008 - The invasive non-native species framework strategy for Great Britain, Defra, London, 42.

15. Department for the Environment, Food and Rural Affairs, 2009 - Wildlife management and invasive non-native species, Defra, London, 147.

16. Dryzek J., 1997 - The Politics of the Earth: Environmental Discourses, Oxford University Press, Oxford, 288.

17. Environment Agency, 2009 - River Basin Management Plan - Anglian River Basin Region, Environment Agency, Bristol, 68.

18. Environment Agency, 2010a - Apply for a consent to trap non-native crayfish, http://www.environment-agency.gov.uk/homeandleisure/recreation/fishing/119096.aspx (accessed 27/08/2010).

19. Environment Agency, 2010b - Crayfish catch return form, http://www.environmentagency.gov.uk/static/documents/Leisure/C_C_R_F_09.pdf (accessed 27/08/2010).

20. European Union, 2000 - Directive 2000/60/EC of the European Parliament and of the Council of 23 October 2000 establishing a framework for Community action in the field of water policy, http://eur-lex.europa.eu/LexUriServ/LexUriServ.do?uri=CELEX:32000L0060:EN:NOT (WWW, accessed 27/08/2010).

21. Fasham M. and Trumper K., 2001 - Review of non-native species legislation and guidance, Defra, Bristol, 145. 
22. Freeman M., Turnbull J., Yeomans W. and Bean C., 2010 - Prospects for management strategies of invasive crayfish populations with an emphasis on biological control, Aquatic Conservation: Marine and Freshwater Ecosystems, 20, 211-223.

23. Gozlan R., Burnard D., Andreou D. and Britton J. R., 2013 - Understanding the threats posed by non-native species: public vs. conservation managers, PLOS ONE, 8, 1, e53200.

24. Gutiérrez-Yurrita P., Martínez J., Bravo-Utrera M., Montes C., Ilhéu M. and Bernardo J., 1999 The status of crayfish populations in Spain and Portugal in Gherhardi F. and Holdich D. (eds), Crayfish in Europe as alien species. How to make the best of a bad situation? Balkema A. A., Rotterdam (Crustacean Issues, 11), 161-190.

25. Hall M., 2003 - Editorial: The native, naturalised and exotic - plants and animals in human history, Landscape Research, 28, 5-9.

26. Hein C., Vander Zanden M. J. and Magnuson J., 2007 - Intensive trapping and increased fish predation cause massive population decline of an invasive crayfish, Freshwater Ecology, 52, 1134-1146.

27. Her Majesty’s Stationary Office (HMSO), 1996 - Statutory Instrument 1996 no. 1104, The Prohibition of Keeping of Live Fish (Crayfish) Order 1996, http://www.opsi.gov.uk/si/si1996/Uksi_19961104_en_1.htm (accessed 27/08/2010).

28. Hickley P. and Chare S., 2004 - Fisheries for non-native species in England and Wales: angling or the environment? Fisheries Management and Ecology, 11, 203-212.

29. Hill A. and Lodge D., 1994 - Diel changes in resource demand - competition and predation in species replacement among crayfishes, Ecology, 75, 2118-2126.

30. Holdich D., Rogers D. and Reynolds J., 1999a - Native and alien crayfish in the British Isles, in Gherhardi F. and Holdich D. (eds), Crayfish in Europe as alien species. How to make the best of a bad situation? Balkema A. A., Rotterdam (Crustacean Issues, 11), 231-236.

31. Holdich D., Gydemo R. and Rogers D., 1999b - A review of possible methods for controlling nuisance populations of alien crayfish, in Gherhardi F. and Holdich D. (eds), Crayfish in Europe as alien species. How to make the best of a bad situation? Balkema A. A., Rotterdam (Crustacean Issues, 11), 245-270.

32. Holdich D., Reynolds J., Souty-Grosset C. and Sibley P., 2009 - A review of the ever increasing threat to European crayfish from non-indigenous crayfish species, Knowledge and Management of Aquatic Ecosystems, 11, 394-395.

33. Joint Nature Conservation Committee, 2010 - 1092 White-clawed (or Atlantic stream) crayfish Austropotamobius pallipes, http://www.jncc.gov.uk/protectedsites/sacselection/species.asp?FeatureIntCode=S1092 (accessed 27/08/2010).

34. Jones P. J. S., 2008 - Fishing industry and related perspectives on the issues raised by no-take marine protected area proposals, Marine Policy, 32, 749-758.

35. Juliano S., Lounibos L. P., Nishimura N. and Greene K., 2010 - Your worst enemy could be your best friend: predator contributions to invasion resistance and persistence of natives, Oecologia, 162, 709-718.

36. Kerby J., Riley S., Kats L. and Wilson P., 2005 - Barriers and flow as limiting factors in the spread of an invasive crayfish (Procambarus clarkii) in southern California streams, Biological Conservation, 126, 402-409.

37. Leach M. and Scoones I., 2005 - Science and citizenship in a global context, in Leach M., Scoones I. and Wynne B. (eds), Science and Citizens: Globalization and the challenge of Engagement, Zed Books, London, 15-40.

38. Lindqvist O. and Huner J., 1999 - Life history characteristics of crayfish: what makes some of them good colonisers? in Gherhardi F. and Holdich D. (eds), Crayfish in Europe as alien species, How to make the best of a bad situation? Balkema A. A., Rotterdam (Crustacean Issues, 11), 2230. 
39. Lowery R. and Holdich D., 1988 - Pacifastacus leniusculus in North America and Europe, with details of distribution of introduced and native crayfish species in Europe, in Freshwater crayfish: biology, management and exploitation, Holdich D. and Lowery R. (eds), Croom Helm, London, 283-326.

40. Mack R., Simberloff D., Lonsdale W. M., Evans B., Clout M. and Bazzaz F., 2000 - Biotic invasions: causes, epidemiology, global consequences and control, Ecological Applications, 10, 689-710.

41. Manchester S. and Bullock J., 2000 - The impacts of non-native species on UK biodiversity and the effectiveness of control, Journal of Applied Biology, 37, 845-864.

42. Millenium Ecosystem Assessment, 2005b - Ecosystems and wellbeing: wetlands and water synpaper, World Resources Institute, Washington D.C., 80.

43. Momot W., 1998 - An example of how exploitation can increase production and yield in a northern crayfish (Orconectes virilis) population, Canadian Special Publication of Fisheries and Aquatic Sciences, 125, 225-233.

44. Moorhouse T. and Macdonald D., 2015 - Are invasives worse in freshwater than terrestrial ecosystems? Wiley Interdisciplinary Reviews-Water, 2, 1-8.

45. Musseau C., Boulenger C., Crivelli A., Lebel I., Pascal M., Boulêtreau S. and Santoul F., 2015 Native European eels as a potential biological control for invasive crayfish, Freshwater Biology, 60, 636-645.

46. Natural History Museum, 2008 - The commercial exploitation of Thames mitten crabs: a feasibility study - report to Defra, NHM, London, 81.

47. Non-Native Species Secretariat, $2009 \quad-\quad$ Be Plant Wise, http://www.nonnativespecies.org/beplantwise/, (accessed 27/08/2010).

48. Non-Native Species Secretariat, 2010 - UK Non-native organism risk assessment scheme - Pseudorasbora parva - Topmouth gudgeon, https://secure.fera.defra.gov.uk/nonnativespecies/index.cfm?sectionid=51 ～(accessed 27/08/2010).

49. Non-Native Species Secretariat, 2011 - UK Non-native organism risk assessment scheme - Pacifastacus leniusculus - signal crayfish, http://www.nonnativespecies.org/factsheet/factsheet.cfm?speciesId=2498 (accessed 16/8/2016), 14.

50. Non-Native Species Secretariat, 2015 - The Great Britain Invasive Non-native Species Strategy, August 2015, Animal and Plant Health Agency, Sand Hutton, York, 11.

51. Peay S., 2001 - Eradication of alien crayfish populations, R\&D Technical Report W1-037/TR1, Environment Agency, Bristol, 60.

52. Peay S., Hiley P. D., Collen P. and Martin I., 2006 - Biocide treatment of ponds in Scotland to eradicate signal crayfish, Bulletin Francais de la Peche et de la Pisciculture, 380-381, 1363-1379.

53. Peay S., 2010 - Invasive non-indigenous crayfish species in Europe: recommendations on managing them, Knowledge and Management of Aquatic Ecosystems, 394-395, 03.

54. Peay S. and Dunn A., 2014 - The behavioural response of the invasive signal crayfish Pacifastacus leniusculus to experimental dewatering of burrows and its implications for eradication treatment and management of ponds with crayfish, Ethology Ecology and Evolution, 26, 277-298.

55. Poulin B., Lefebvre G. and Crivelli A., 2006 - The invasive red swamp crayfish as a predictor of Eurasian bittern density in the Camargue, France, Journal of Zoology, 273, 98-105.

56. Rabeni C., 1992 - Trophic linkage between stream centrarchids and their crayfish prey, Canadian Journal of Fisheries and Aquatic Science, 49, 1714-1721.

57. Ramsar Convention, 2003 - New guidelines for management planning for Ramsar sites and other wetlands - COP 8, Valencia, Spain. http://www.ramsar.org/cda/en/ramsar-activities-newguidelines-for/main/ramsar/1-63\%5E20857_4000_0__ (accessed 28/08/2010). 
58. Reeve I. D., 2004 - The removal of the North American signal crayfish (Pacifastacus leniusculus) from the River Clyde, Scottish Natural Heritage Commissioned Report no. 020 (ROAME no. F00LI12), 55.

59. Reyes-García V., Menendez-Baceta G., Aceituno-Mata L., Acosta-Naranjo R., Calvet-Mir L., Domínguez P., Garnatje T., Gómez-Baggethun E., Molina-Bustamante M., Molina M., Rodríguez-Franco R., Serrasolses G., Vallès J. and Pardo-de-Santayana M., 2015 - From famine foods to delicatessen: Interpreting trends in the use of wild edible plants through cultural ecosystem services, Ecological Economics, 120, 303-311.

60. Robson C., 2007 - How to do a Research Project - A Guide for Undergraduates, Blackwell Publishing, Oxford, 176.

61. Roy H., Preston C., Harrower C., Rorke S., Noble D., Sewell J., Walker K., Marchant J., Seeley B., Bishop J., Jukes A., Musgrove A., Pearman D. and Booy O., 2014 - GB Non-native Species Information Portal: documenting the arrival of non-native species in Britain, Biological Invasions, 16, 2495-2505.

62. Scholtz G., Braband A., Tolley L., Reimann A., Mittemann B., Lukhaup C., Steuerwald F. and Vogt G., 2003 - Parthenogenesis in an outsider crayfish, Nature, 421, 806.

63. Selge S., Fischer A. and van der Wal R., 2011 - Public and professional views on invasive nonnative species - A qualitative social scientific investigation, Biological Conservation, 144, 30893097.

64. Stebbing P., Watson G., Bentley M., Fraser D., Jennings R, Rushton S. and Sibley P., $2002-$ Chemical ecology: A role in the control of non-native species of crayfish? in Management and Conservation of Crayfish - Proceedings of a conference held on 7th November 2002 Holdich D. and Sibley P. (eds), Environment Agency, Bristol, 175-184.

65. Stebbing P., Longshaw M. and Scott A., 2014 - Review of methods for the management of nonindigenous crayfish, with particular reference to Great Britain, Ethology, Ecology and Evolution, 26, 204-231.

66. Stokes K., O’Neill K., Montgomery W., Dick J., Maggs C. and McDonald R., 2006 - The importance of stakeholder engagement in invasive species management: a cross-jurisdictional perspective in Ireland, Biodiversity and Conservation, 15, 2829-2852.

67. Stokes K., O'Neill K., Montgomery W., Dick J., Maggs C. and McDonald R., 2006 - The importance of stakeholder engagement in invasive species management: a cross-jurisdictional perspective in Ireland, Biodiversity and Conservation, 15, 2829-2852.

68. Taugbøl T. and Skurdal J., 1999 - The future of native crayfish in Europe: How to make the best of a bad situation? in Gherhardi F. and Holdich D. (eds), Crayfish in Europe as alien species. How to make the best of a bad situation? Balkema A. A., Rotterdam (Crustacean Issues, 11), 271-280.

69. Taugbøl T., 2004 - Exploitation is a prerequisite for conservation of Astacus astacus, Bulletin français de la pêche et de la pisciculture, 372-373, 275-279.

70. Valentine G., 1997 - "Tell me about: using interviews as a research methodology", in Methods in Human Geography Research, Flowerdew R. and Martin D. (eds), Addison Wesley Longman Ltd., Essex, UK, 110-128.

71. Van Eijck M. and Roth W.-M., 2007 - Keeping the local local: recalibrating the status of science and traditional ecological knowledge (TEK) in education, Science Education, 91, 926-947.

72. West R., 2009 - Non-native crayfish: a new approach to trapping: A review of signal crayfish trapping on the River Lark at Barton Mills, Suffolk from 2001-2009, Lark Angling and Preservation Society, 14.

73. Williams F., Eschen R., Harris A., Djeddour D., Pratt C., Shaw R., Varia S., LamontagneGodwin J., Thomas S. and Murphy S., 2010 - The economic of invasive non-native species on Great Britain, CABI project report CAB/001/09, Project VM10066, 198.

74. Wynne B., 1992 - Misunderstood misunderstanding: social identities and public uptake of science, Public Understanding of Science, 1, 281-304. 